Volume 5 Issue 2, June 2018

\title{
Comparative Juridical Analysis Of Witness's Position In Notarial Agreement Making Based On Islamic Law And Public Notary Law (UUJN)
}

\author{
Meta Agulegistin ${ }^{1}$ and Akhmad Khisni ${ }^{2}$
}

\begin{abstract}
The problem of witnesses has been seen as a significant problem. It requires the reinterpretation of text messages that considered a male witness is equal to two women. The issues raised are: How is the position of witness when making notarial agreement in Islamic law, How is the position of witness when making notarial agreement according to UUJN (Public Notary Law), and What is the similarity and difference of witness position in making notarial agreement according to Islamic law and UUJN. The research method used was Juridical Normative with Regulations approach, Conceptual Approach, and case Approach. Research result found that Firstly, the witness is someone who can give a statement or information that he knows about what the actual events. Another meaning is that a witness is a person who is asked to be present to witness a legal event; Secondly, a witness is a person who can give a definite statement because the person knows the actual event, and even the other meaning of the witness is the person who is asked to attend to witness an event. The person who is asked to be a witness is a qualified person and considered to be well-informed of what he or she is witnessing. And Third, the equation has a purpose for justice and truth can be enforced by the presence of witnesses and the difference Act No.40 of 2014 on the position of a notary. It is originated from the rules of legislation and as evidence, as well as the differences in the conditions specified. On the other hand, Islamic law comes all source of regulations are from Al Quran and As-Sunnah.

Keywords: Comparison; Position of Witnesses; Notarial Agreement; Islamic Law; Public Notary Law.
\end{abstract}

\section{Introduction}

Indonesia is a legal state with all cultures owned. In the development of law that occurred in Indonesia, Islamic law is included in the source of law, especially in the field of Civil Law. Reality that can be seen is Indonesia is dominated by Muslim, so there are many Muslims want to make Islamic law as a positive law.

The rapid development of Islamic economic institutions today is also followed by the increasing variety of Islamic business transactions and forms of agreement that demand to use the rules of Islam (sharia) ${ }^{3}$. One of the most important roles in a court is the presence of witnesses, since the witness has a position as another means of evidence to provide information on an event/dispute. In the text of the fiqh books, the matter of testimony in the court is required to be male except for the testimony relating to property rights (huquq al-amwal) or the right of the body. As if women's rights are not recognized when compared to men, this means there is a gap between the fiqh texts and the reality of society. When looking at the moral message of the Qur'an that the position of men and

\footnotetext{
${ }^{1}$ Student of Master Program (S2) of Notaries Faculty of Law UNISSULA Semarang Indonesia email metaagulegistin30@gmail.com

2 Lecturer of Faculty of Law UNISSULA

${ }^{3}$ Hasballah Thaib and Iman Jauhari 2004 Kapita Selekta Hukum Islam Pustaka Bangsa Press Medan p. 213
} 
women is equal. 4

The problem of witnesses has been seen as a significant problem. It requires reinterpretation of the text messages that had been considered a male witness is equal to two women. However, before a further discussing, we will know earlier about the definition of witness. According to the etymology (language) the word of witness in Arabic is known as Asy-syahadah is the form of masdar isim from the word syahida-yasyhadu which means to attend, witness (with their own eyes) and knowing. The word syahadah also means al-bayinan (proof), yamin (oath) and iqrar (acknowledgment) ${ }^{5}$. In terminology (term), Al-Jauhari states that testimony means certain news. Musyahadah means something real, because the witness is a person who witnesses something that other people do not know. It is also said that testimony means a person who tells correctly what he/she sees and hears ".6

Likewise with the Notary, in making Notarial agreement, the Notary always use the theory of witnesses of the Civil Code and Act No.30 of 2004. While the theory of witnesses in Islamic Law is different from the Book of Civil Law and Act No.30 of 2004, especially about the conditions of the person who may be a witness. The confrontation or the person who wants to make agreement by the notary is majority Muslim, where Muslims certainly stick to the law of religion. Therefore, a notary as a certificate maker must follow the teachings of Islam if the agreement made by the notary itself is intended for Muslims.

Based on the above descriptions, it is necessary to further study the comparison of the above matters: "Juridical Analysis on Comparative Study of the Status of Witnesses in the Notarial Agreements Based on Islamic Law and the Law of Public Notary Law (UUJN)"

\section{Research Methods}

This research conducted is the normative juridical legal research7. According to Peter Mahmud Marzuki that normative legal research is "a process of finding a rule of law, legal principles, and legal doctrines to address the legal issues faced"s. It was conducted by examining library materials or secondary data. Based on research typology used and seen from its nature, this research conducted by writer is descriptive. It is aimed to describe precisely the nature of an individual, state, symptom or certain group, or to determine frequency of a symptom. ${ }^{9}$

With normative juridical research methods, the object of legal juridical-normative research includes (1) research on legal principles, (2) research on legal systematics, (3) research on the level of legal synchronization, (4) legal history research, And (5) comparative law studies. ${ }^{10}$

\footnotetext{
${ }^{4}$ Ahmad Baidowi 2005 Tafsir Feminis Kajian Perempuan dalam Al-Qur'an dan Mufasir Kontemporer First Edition Nuansa Publisher Bandung p. 117.

${ }^{5} \mathrm{~A}$. Warson Moenawwir 2002 Al-Munawir Kamus Arab-Indonesia $25^{\text {th }}$ Edition Pustaka Progresif Surabaya p. 746-747.

${ }^{6}$ Ihsanudin Mohammad Najib Sri Hidayati (eds) p. 94

7Soerjono Soekanto and Sri Mamudji 1985 Penelitian Hukum Normatif: Suatu Tinjauan Singkat Raja Grafindo Persada Jakarta p.5

${ }^{8}$ Hidayatullah, Gunarto, Anis Mashdurohatun and Ahmad Rofiq, "Ideal Reconstruction of Law

Number 41 Year 2004 on the Position and the Authority of Money Wakaf Law Based on Justice Values Towards Improving the Moslem Economyc", in International Journal of Economic Research, Volume 14 Number 152017 p. 317

${ }^{9}$ Soerjono Soekanto 2015 Pengantar Penelitian Hukum UI-Press Jakarta p.10.

${ }^{10}$ Anis Mashdurohatun, Zaenal Arifin and Gunarto, "The Inconsistency of Parate Execution Object Warranty of Rights in Banking Credit Agreement in Indonesia", in International Journal of Applied Business and Economic Research Volume 15 Number 202017 p. 269
} 
The method of problem approach used in this research was: The statute approach is used to perform traceability, inventory and review of positive law legislation related to witness position in Islamic law and Public Notary law. The conceptual approach is an approach that moves from the views and doctrines that develop in the science of law. Both doctrine and view were used to see the legal doctrine of the scholars. Further, the case approach is the approach by doing the tracking along with the comparative study of witness status according to Islamic law and the Public Notary law. ${ }^{11}$

Normative legal research has always focused on secondary data sources. Secondary data on research can be distinguished into primary legal materials, secondary legal materials and tertiary legal materials. ${ }^{12}$

- Primary legal material, which is a binding legal material in the form of legislation are from: Al-Qur'an and Hadith; Compilation of Islamic Law; Public Notary Law; The Civil Code

- Secondary Legal Material which is the legal materials that give explanation about primary law material, in the form of: Books; Journals; Magazines; Media articles;

\section{Result And Discussion}

\subsection{Position of Witnesses in the Notarial Agreements According to Islamic Law}

Imam Al-Syafi'i stated that an object which is controlled by the owner and then charged by a person who has due to a circumstance, then the plaintiff must have evidence. If he/she can prove and take it otherwise the defendant must swear by canceling the lawsuit. However, if he does not want to swear, the defendant will lose his right and the object is granted to the plaintiff ${ }^{13}$. Meanwhile, according to Ibn Qayyim, testimony is part of bayyinah, anything that can reveal and explain the truth to a matter disputed. ${ }^{14}$

Based on the explanation above, the witness is someone who can give a statement or information that he knows about what the actual events. Another meaning is that the witness is the one who is asked to be present to witness a legal event, the witness is a qualified person and is well understood of what he or she witnesses. Generally, the witnesses who may be brought to trial must meet the following requirements of Muslims, Healthy mind, Baligh (mature) and Not wicked.

Before giving testimony, all witnesses should be sworn by a judge. Those who are rejected to be witnesses are as follows, he/she is hostile to the litigant, Mahram, has interest in the issue/matter, mentally ill, Fasik (Q. IV: 54) is the one who likes to conceal the truth and reveal the wrong, and Safih (Q.IV: 5 ) is the weak sense or under forgiveness. ${ }^{15}$

The testimony in this case is embodied in a variety of livelihoods. As explained by Imam Ali bin Khail, he divided the various testimonies on the basis of the number of witnesses, they are $^{16}$ : with four men witnesses such as adultery/sexual harassment and lian. Two male

\footnotetext{
${ }^{11}$ Johny Ibrahim 2005 Teori \& Metode Penelitian Hukum Normatif First Edition Bayu Media Malang p.246

${ }^{12}$ Ronny Hanitijo Soemitro 1990 Metodelogi Penelitian Hukum dan Jurimetri Ghalia Indonesia Jakarta p.11-12

${ }_{13}$ Aris Bintania 2013 Hukum Acara Peradilan Agama dalam Kerangka Fiqh al-Qadha Second

Edition Rajawali Pers Jakarta p. 72

${ }^{14}$ Abdul Manan 2006 Penerapan Hukum Acara Perdata di Lingkungan Peradilan Agama Third

Edition Kencana Jakarta p. 374.

${ }^{15}$ Sulaikin Lubis 2005 Hukum Acara Perdata Peradilan Agama di Indonesia First Edition Kencana Jakarta p. 136.

${ }^{16}$ Muhammad Nur Abduh 2012 Persaksian Perempuan dalam Al-Quran Alauddin University

Press Makassar p. 82-83.
} 
witnesses such as marriage, reconcile", thalaq, iddah, tamlik, trade and others, with one man and two women.

All of these testimonies are accepted in all areas of law except the Shafi'iyah and alMalikiyah. On the other hand, Hanabilah only allows the testimony of one man and two women on muamalah maaliyah matters (transactions) as indicated by the Qur'an (Q.S. alBaqarah (2): 282 ) such as sale and purchase, leases, grants, washiyat, pledge, agreement.

\subsection{Position of Witness In a Notary Law}

In Article 40 of the UUJN (Public Notary Law), the amendment has been clearly regulated regarding the witness in the inauguration and the making of notarial agreement in the form of a requirement for witnesses. The provisions stipulated in Article 40 UUJN, to be a witness, someone has fulfill these following conditions:

- Every Agreement read by a Notary shall be attended by at least 2 (two) witnesses, unless the rule of law determines otherwise.

- Witnesses as referred to in paragraph (1) must meet the following requirements: at least 18 (eighteen) years old or previously married, able to do legal agreements, understand the language used in the Agreement, may affix signatures and has no marital or blood relations in straight line up or down without any degree limitation and line to the side up to third degree with Notary or parties.

- Witnesses as referred to in paragraph (1) shall be recognized by a Notary or introduced to a Notary or explained about his or her identity and authority to the Notary by the applicant.

- The identification or representation of the identity and authority of the witness is expressly stated in the Agreement.

Witness in agreement of Notary is the witness who participated in making the agreement. Witnesses participate in the creation of agreements and that is why they are called instrumenter witnesses (instrumentaire getuigen) by signing, giving testimony of the truth of the existence and fulfillment of the formalities required by law, mentioned in the agreement and witnessed by witnesses. 15 (fifteen) witness agreement or are often called instrumenter witness, when summoned in court for questioning is no longer as a witness in a agreement that only looks at the formalities of the inauguration of the agreement, but has become a public witness who can be asked for information about the case or dispute involving the agreement made by a Notary. This can be seen in the Criminal Procedure Code and the Civil Procedure Law which regulates the proof of witness testimony.

The relation with the contents of the notarial agreement is still to be the responsibility of the notary if there is a problem in the hearing related to the notarial agreement, because the notary is communicating directly with the applicant. So, the notary employee cannot be held responsible if he becomes a witness in the court related to the contents notarial agreement, because the responsibility of notary employee is only limited to prepare agreement which is accounted to notary. It is different if the notary employee gives testimony in the hearing in his capacity as an instrumenter witness. The notary employee is personally responsible for what he has witnessed is related to whether the notary has fulfilled the formalities of the inauguration of the agreement/verlijden as instructed by the Law - Invite Notary. ${ }^{17}$

\subsection{Comparative Status of Witnesses in Islamic Law and UUJN (Notary Law)}

\footnotetext{
17 Rosmala Dewi Perlindungan Hukum Terhadap Saksi Instrumenter Dalam Akta Notaris accessed from http:/www.google.com/lib.ui.ac.id/filedigital/T31529
} 
Volume 5 Issue 2, June 2018

\begin{tabular}{|l|l|l|}
\hline \multicolumn{1}{|c|}{ Explanation } & \multicolumn{1}{|c|}{ Islamic Law } & \multicolumn{1}{c|}{ UUJN } \\
\hline $\begin{array}{l}\text { Legal Basis of } \\
\text { Witness }\end{array}$ & Q.S. A/-Baqarah verse 282 & Article 39-41 \\
\hline $\begin{array}{l}\text { Agreement Legal } \\
\text { Basis }\end{array}$ & Q.S. A/-Maidah verse 1 & Article 1320 Civil Code \\
\hline $\begin{array}{l}\text { The definition of } \\
\text { witness }\end{array}$ & $\begin{array}{l}\text { The person who gives the } \\
\text { correct information about what } \\
\text { is seen, experienced, witnessed } \\
\text { and what is heard about a a } \\
\text { particular event }\end{array}$ & $\begin{array}{l}\text { Witness is a third person who } \\
\text { participated in the making of the } \\
\text { agreement and witness was also } \\
\text { called instrumentair witness } \\
\text { (instrumenter getugen). }\end{array}$ \\
\hline $\begin{array}{l}\text { Conditions to } \\
\text { become witness }\end{array}$ & $\begin{array}{l}\text { Islam, Adults / Baligh, } \\
\text { Rational, Fair, Speaks Good, } \\
\text { Memory and Thorough }\end{array}$ & $\begin{array}{l}\text { 2 (two) witnesses, At least 18 } \\
\text { (eighteen) years old or married, } \\
\text { their identity and authority, } \\
\text { Introduction or statement }\end{array}$ \\
\hline Proof & $\begin{array}{l}\text { Proof that not only through } \\
\text { witnesses but also through } \\
\text { other evidence, }\end{array}$ & $\begin{array}{l}\text { Witnesses are required if } \\
\text { evidence by letter or writing is } \\
\text { absent or incomplete to support } \\
\text { and corroborate the truth of the } \\
\text { arguments }\end{array}$ \\
\hline
\end{tabular}

\section{Closing}

\subsection{Conclusion}

- The position of witnesses according to Islamic law is mandatory in every implementation of the contract, because the witness is a harmonious and legal requirement of a contract. In Islamic law the testimony of two women is equivalent with one man's testimony. This has been explained by Al-Quran letter of Al-Baqarah Verse 282. The law of bringing witnesses to meet all requirements is a must, giving legal testimony Fardhu ain "a witness must bear his testimony in truth and should not hide it from what he knows.

- The position of witness in Act No.30 of 2014 on the position of the Notary shall be attended by at least 2 (two) witnesses and they must meet the requirements of being 18 years old, proficient, understanding the language used, can make signature, has no marital relationship or blood relation either in a straight line up or down without any degree limitation and lateral line up to third degree with Notary or parties, and witnesses must be recognized by Notary or introduced to be explained about their identity and authority to Notary by the appilicant.

- Comparisons that have been made to the position of the witness as evidence by Act No.40 of 2014 on the position of Notary and Islamic law, the equation has the purpose that justice and truth can be established by witnesses in the making of the contract or notarial agreement. If the conclusion is different, in Act No.40 of 2014 on the position of Notary comes from the rules of legislation and as evidence, as well as the existence of differences in the conditions specified. Whereas in Islamic law, all sources are from Al-Qur'an and As-Sunnah. So that the witness is said to be harmonious ie determine whether or not a legal act is in the matter of making the contract.

\subsection{Suggestion}

- Notary in his duty to make a agreement in terms his position, according to Islamic law should notaries must be a Moslem in making Notarial agreement in accordance with Islamic law. On the other hand, if all parties are moslem, it is better to use Islamic law, 
in order notary to perform duty as notary according with the Islamic Law as well as those parties, but still not adjacent the Law of Notary Position.

- The instrumentair position in making the agreement is a very helpful to the performance of the Notary. Therefore, if there is a legal matter in the court against the agreement where there is an instrumentair witness therein, UUJN should accommodate the protection of the instrumentair witness, so that the position of the istrumentair witness also gets legal protection.

- Despite the insufficient differences in witness status under UUJN and Islamic law, UUJN and Islamic law may still be the basis for upholding the justice. The importance of the testimony is what makes God forbid the person who keeps the information, while he knows the fact.

\section{References}

[1] Abdul Manan 2006 Penerapan Hukum Acara Perdata di Lingkungan Peradilan Agama Third Edition Kencana Jakarta.

[2] Ahmad Baidowi 2005 Tafsir Feminis Kajian Perempuan dalam Al-Qur'an dan Mufasir Kontemporer First Edition Nuansa Publisher Bandung.

[3] Anis Mashdurohatun, Zaenal Arifin and Gunarto, "The Inconsistency of Parate Execution Object Warranty of Rights in Banking Credit Agreement in Indonesia", in International Journal of Applied Business and Economic Research Volume 15 Number 202017

[4] Aris Bintania 2013 Hukum Acara Peradilan Agama dalam Kerangka Fiqh al-Qadha Second Edition Rajawali Pers Jakarta.

[5] Hasballah Thaib and Iman Jauhari 2004 Kapita Selekta Hukum Islam Pustaka Bangsa Press Medan.

[6] Hidayatullah, Gunarto, Anis Mashdurohatun and Ahmad Rofiq, "Ideal Reconstruction of Law Number 41 Year 2004 on the Position and the Authority of Money Wakaf Law Based on Justice Values Towards Improving the Moslem Economyc", in International Journal of Economic Research, Volume 14 Number 152017

[7] Johny Ibrahim 2005 Teori \& Metode Penelitian Hukum Normatif First Edition Bayu Media Malang.

[8] Muhammad Nur Abduh 2012 Persaksian Perempuan dalam Al-Quran Alauddin University Press Makassar.

[9] Ronny Hanitijo Soemitro 1990 Metodelogi Penelitian Hukum dan Jurimetri Ghalia Indonesia Jakarta.

[10] Rosmala Dewi Perlindungan Hukum Terhadap Saksi Instrumenter Dalam Akta Notaris accessed from http:/www.google.com/lib.ui.ac.id/filedigital/T31529

[11] Soerjono Soekanto 2015 Pengantar Penelitian Hukum UI-Press Jakarta.

[12] Soerjono Soekanto and Sri Mamudji 1985 Penelitian Hukum Normatif: Suatu Tinjauan Singkat Raja Grafindo Persada Jakarta.

[13] Sulaikin Lubis 2005 Hukum Acara Perdata Peradilan Agama di Indonesia First Edition Kencana Jakarta.

[14] Warson Moenawwir 2002 Al-Munawir Kamus Arab-Indonesia 25th Edition Pustaka Progresif Surabaya. 